\title{
Net Working Capital and the Profitability: Empirical Evidence form Amman Stock Exchange
}

\author{
Zaher Abdel Fattah Al-Slehat ${ }^{1}$, Bader Mustafa Al-Sharif ${ }^{1}$ \\ ${ }^{1}$ Assistant Professor, Faculty of Business, Tafila Technical University, Jordan \\ Correspondence: Zaher Abdel Fattah Al-Slehat, Faculty of Business, Tafila Technical University, At-Tafila, P.O. \\ Box 179, Tafila, 66110, Jordan.
}

Received: February 5, 2019

Accepted: March 4, 2019 Online Published: March 13, 2019

doi:10.5539/ibr.v12n4p12

URL: https://doi.org/10.5539/ibr.v12n4p12

\begin{abstract}
The current study investigates empirically the relationship between the net working capital and the profitability of the industrial companies for the period of 9 years from 2009-2017.

To fulfill this aim, the researcher used the analytical descriptive method on a sample consisted of 26 industrial companies listed in Amman Stock Exchange (ASE). The empirical result shows that net operating income and return on asset have positive relationship with net working capital. However, there is no relationship between net working capital and profit margin. The study recommends that to more attention for investing the net working capital by determining investment opportunities that reflect positively on profitability. Additionally, managers should raise the awareness of their employees regarding the importance of internal and external investment to increase the market share.
\end{abstract}

Keywords: net working capital, net operating income, profit margin, return on asset

\section{Introduction}

The way of gaining and investing money appropriately and efficiently is regarded as one of the management priorities; this can be achieved through the ability of company to manage their assets, requirements and owners' equity. This means an effective system of planning and controlling is needed to decide the expected financial requirements which, by its turn, will be reflected in achieving the basic goal of the companies; namely the profitability (Jiricek and Dostalova 2010; Lee and Lee, 2006).

Fama and French (2002) and Ehrhardt and Brigham (2003) refer to the essence of the financial management in finding value for the shareholders. They added that the profitability is one important factor in financing companies, thus the financial goal that the financial management tries to fulfill varies from one to another as illustrated in Table 1 below:

Table 1. The Financial Goal

\begin{tabular}{ll}
\hline Organization & Financial Objectives \\
\hline Companies (Limited and Unlimited) & Wealth or Value Maximization \\
Public Corporations & Profit/Revenue Maximization \\
Federal, State or Local Government & Revenue Maximization \\
Charities, Clubs, Societies & Revenue Maximization \\
\hline
\end{tabular}

*source: adapted from Obara and Eyo (2000)

Hence, the financial management has to achieve a list of tasks in order to increase the future income and decrease the expected risk-rate (Subramanyam and Wild, 2009; Jiricek and Dostalova, 2010). These tasks are:

A- Achieving a growth in equity, profits and owners' returns.

B- Providing the necessary capital to establish and operate company and enabling investment.

C- Making decision concerning the provided capital to buy financial assets, technology development and financing company operation (inventory, claims and operation costs).

D- Deciding on the distribution or re-investment of profits. 


\section{Theoretical Framework}

\subsection{Net Working Capital}

"Working capital may be referred to as net working capital generally means: current assets less current liabilities , where the concept of which appears in the statement of financial position / Balance Sheet is characterized by its fast turnover and its ease to convert it into liquid cash and current liabilities that matures and due for payment within a year or less. (Kaddumi and Ramadan, 2012)

The net working capital represents the difference between the current assets and the current liabilities and the relationship between them. Moreover, it refers to the degree of confidence in the ability of the current assets to fulfill the short-term obligations (Meyers, 2003; Ross, et al, 2010; Brigham \& Houston, 2007; Brealey and Myers, 2006; Brealey et al, 2015).

The net working capital includes the current assets (cash, short-term investments, receivables, inventory and prepaid expenses) and the current liabilities (Account payables, Short term borrowings) (Arnold, 2008). The increase in net working capital is recognized as a positive indicator for the ability of the company to fulfill its obligations in short time (Gitman and Zutter, 2012) and, as a result, the financial manager should evaluate the best level of these elements (the current assets and liabilities) in a way that achieves trade-off between the element of return and risk (Lambersom, 1995).

Consequently, Paramasivan and Subramanian (2009) stated that the working capital is used to buy raw materials, pay salaries for employees, pay daily expenses, and maintenance expenses. It is also used to know the stability of the financial state of the companies and their abilities to fulfill their obligations as they come due.

Ross et al, (2010) state that the Net working capital is positive when current assets are greater than current liabilities. This means the cash that will become available over the next 12 months will be greater than the cash that must be paid out.

\subsection{Profitability}

\subsubsection{Definition of Profitability}

Profitability is regarded as a goal for all companies and a measurement to judge the efficiency of administrating their operational, financial and investment processes. It also refers to the relationship between the earned incomes and the investments that leads to this incomes, this can be measured through the relationship between the profits and sales or through the relationship between profits and investments that caused them. (Amirthalingam and Balasundaram, 2014; Dekan, 2009)

Necessarily, this leads to make appropriate financial and investment decisions that are positively reflected on profitability in light of a suitable volume of investment (Balasundaram, 2009). This might be achieved by making important decisions i.e. The investment decision and finance decision in the working capital through the trade-off between the return and risk factors (Brigham and Ehrhardt, 2011).

\subsubsection{Measures of Profitability}

Subramanyam and Wild (2009) indicated that profitability was analyzed on the basis of the following factors:

1. The investments: This could be done by evaluating the financial rewards of suppliers of the capital either by ownership or debit.

2. The operating performance: to assess the profit margin of the operating activities.

3. Investing or using the assets: to evaluate the effectiveness and efficiency of the assets to create sales.

Many measures could be used to find out the profitability of companies such as net operating income, profit margin and the return on assets (Ross, et al, 2010; Vance, 2003).

A. Net operating income: Net operating income is a suitable tool in assessing the profits of companies, if the profit is high, this means the performance is good, and so the quality of the company profit increases. However, if the profit is low, this means there are high administrative, sales or distribution expenses as stated by Gathuya (2005) and Anjum, et al (2012).

B. Profit margin: This measures the net income for each dollar from sales. A low profit margin refers to the different financial strategies adapted by companies not to a problem in the operating processes. Therefore, if the profit margin in a company is low, this might lead to a high rate of return on the investments of stakeholders because of the financial leverage. On the other hand, if the rate of return is high, this indicates 
a good performance of the company, high net income and a notable growth. (Brigham and Houston, 2007; Lee and Lee, 2006)

C. The return on assets: This measures the rate of profitability on assets or its final productivity, the amount of fulfilled wealth due to investing the assets: if this rate is high (for the industrial or historical criterion), this, according to (Gitman, 2002; Edmond, et al, 2006), means the performance and profit are good.

\section{Literature Review}

Evci and sak (2018) investigated the tradeoff between working capital management and firm's profitability by using the annual data for the period 2005-2016 of 41 firms listed on BIST Industrial Index in Turkey. Findings showed the existence of tradeoff working capital management and profitability. And a negative relationship exists between return on assets and payables deferral period, cash conversion cycle, the ratio of short-term financial debts to short-term debts, and the ratio of fixed assets to total assets while return on assets is positively related to inventory conversion period and sales growth.

To examine the impact of net working capital levels on the growth of companies, AbuHommous (2017) conducted his study on sample of 111 Jordanian companies that were listed in Amman Stock Exchange in the period between 1999-2015. The study showed that there was a positive impact of investing the working capital on growth of companies. Additionally, the study revealed that the small companies grew faster than the big ones.

Shahzad et al (2015) tested the effect of working capital management on profitability of cement industry of Pakistan. The study sample consisted 12 listed firms in Karachi stock exchange (KSC) for the time period of 2007-2013, the results show that through fitting working capital management the organization can expand its profitability, The study also found that the working capital must be managed efficiently to increase its profitability.

Kaddumi and Ramadan (2012) investigated the impact of working capital management on the performance of companies measured by profitability. The study was conducted on a sample consisted of 49 industrial Jordanian companies that were listed in Amman Stock Exchange in the period between 2005-2009. The study proved that working capital management and performance were positively related to each other. The study showed that the effective management of the working capital increased the wealth of stakeholders.

Qazi et al, (2011) investigated the impact of working capital of firm's profitability; the study was conducted on a sample of 20 companies from oil, gas and automobile industry listed in Karachi Stock Exchange during (2004-2009). The results of the study found out only net working capital is positive and significant with profitability, and numbers of days of account receivable and inventory turnover in days are positive but insignificant, and all other independent variables are negative and insignificant.

Popescu and Pirvutoiu (2009) studied the analysis of the net working capital of the agricultural companies (grain production companies) in years 2005-2009. The study showed that the net working capital had a positive value in the way which the ability of companies increased to deal with short-term debts and the expected operating expenses.

Finally, Raheman and Nasr (2007) studied the relationship between working capital management and profitability for a sample of 94 companies listed on the Karachi Stock Exchange for the period 1999-2004. The results showed that there was a strong negative relationship between variables of the working capital management and profitability of the firm, and negative relationship between liquidity and profitability, also a significant negative relationship between debt used by the firm and its profitability.

\subsection{This Study}

This study differs from the previous studies as it is considered an attempt to link three variables which explicitly seem independent, but they are working together as one unit; the financial managements of companies show high interest in these variables in both sides: practical and theoretical.

Practically, these indicators reflect the ability of companies for financial planning and making suitable decision concerning investment optimally in net working capital which leads to profitability. On the other hand, the financial management, theoretically, is still a matter of discussion and interest by researchers since it began in the middle of the $20^{\text {th }}$ century till now due to its vital role in improving profitability.

More specifically, and from the reviewing previous studies there is no past studies conducted to found the relationship between net working capital and profitability measured by (net operating income, profit margin and return on assets). Accordingly, the current study attempts to identify the relationship between net working capital and profitability on industrial companies sector. 


\section{Significance of the Study}

The significance of the study is demonstrated in the following points:

A. The importance of the net working capital that is reflected on the profitability of the listed industrial companies in the Amman Stock Exchange during the period under study.

B. This study is an attempt to find a relationship between the different variables which are the net working capital and profitability measured by the net operating income, profit margin and the return on assets since these variables work to redirect money towards investment opportunities to positively cause profitability of company.

C. The importance of using the results of this study in Jordan (as a developing country), and therefore attract investments that enhance the activity of the Amman Stock Exchange, As well as its importance to market participants such as investors, shareholders, brokers, creditors and others.

\section{Research Hypotheses}

The current study aimed to testing the relationship between net working capital and profitability on Jordanian industrial sector. Therefore, the researcher formulates the hypothesis of study as follows:

H0: There is no statistically significant relationship at $(\alpha \geq 0.05)$ between the net working capital and the profitability of companies. Based on this hypothesis, the following sub-hypotheses are derived:

H0-1: There is no statistically significant relationship at $(\alpha \geq 0.05)$ between the net working capital and the profitability of companies whereas that profitability is measured by the net operating income.

H0-2: There is no statistically significant relationship at $(\alpha \geq 0.05)$ between the net working capital and the profitability of companies whereas that profitability is measured by the profit margin.

H0-3: There is no statistically significant relationship at $(\alpha \geq 0.05)$ between the net working capital and the profitability of companies whereas that profitability is measured by the return on assets.

\section{Research Methodology}

The current study uses the descriptive and analytically methodology by using the indicator of the net working capital and indicators of profitability.

\subsection{Population and Sample Study}

The populations of study are all industrial companies listed in Amman Stock Exchange in period between 2009-2017. In addition to, the study sample included 26 companies were chosen to be the sample of the study under the following conditions:
A. Availability of all required data to examine the variables.
B. No merger process occurred.
C. The fiscal year ends in $31^{\text {st }}$ of December.
D. Availability of the financial reports for all companies.

\subsection{Data Collection}

In the current study, a plethora of books, research papers, articles, theses that relate to the topic of this study, the annual financial reports of companies under study, the reports and briefs issued by Amman Stock Exchange are adopted as sources of data.

\subsection{Model of Study}

The following model is adapted to present the specific views of the problem and its features concerning the relationship between the net working capital and profitability. Nufazil (2018) and Sheikh, et al (2016) were used to deal with the independent variable, while Kaddumi and Ramadan (2012) were adapted to study the dependent variables. Figure 1 below illustrates this relationship: 


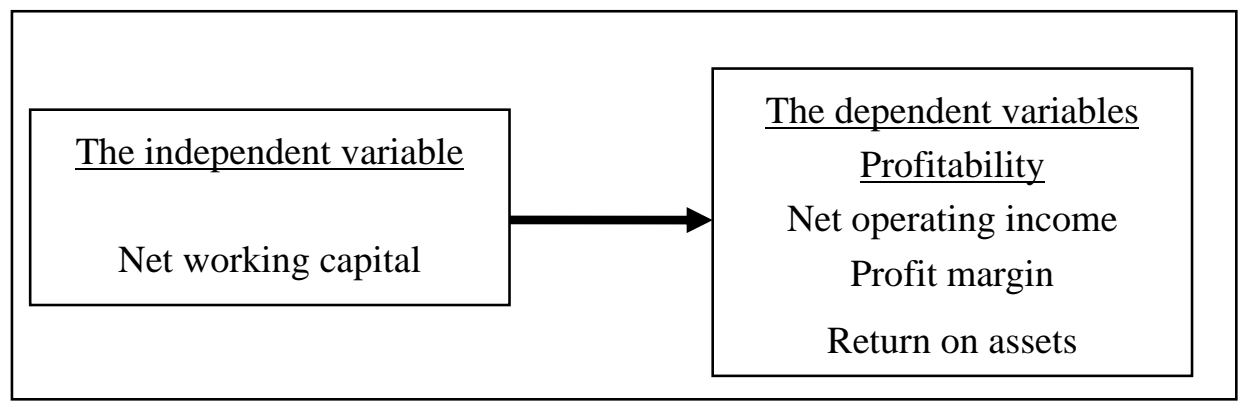

Figure 1. Model of Study

*Source: prepared by the researcher based on previous studies and theoretical.

\subsection{Variables of Study}

The variables of study were measured according to the following:

I. The Independent Variable:

The independent variable was measured according to the following: (Ross, et al, 2003; Gitman and Zutter, 2012)

A. Net working capital: it is the difference between the current assets and current liabilities as presented in this formula:

Net working capital $=$ current assets - current liabilities

II. The Dependent Variables:

The dependent variables are the indicators of profitability i.e. the net operating income, the profit margin and the return on assets. They are measured as follows:

A. Net operating income: It is measured by calculating the gross profit minus the general and administrative expenses minus selling and distribution expenses. It is presented in the following formula :( www.ase.com.jo) Net Operating Income $=$ Gross Profit - General and Administrative Expenses-selling and Distribution Expenses

B. The profit margin: It is calculated by the net income divided by the sales (Brealey, et al, 2011; Lee and Lee, 2006). This is presented in this formula:

Profit margin $=$ net income $\div$ sales

C. The return on assets: It is the net income after tax divided by total assets (Andrew, 2006). It is shown in this formula:

Return on assets $=$ net income after tax $\div$ total assets

\section{The Statistical Analysis}

\subsection{The Descriptive Analysis}

The second table shows the descriptive analysis for the variables of the study. It illustrates the Median and the standard deviations for all variables.

Table 2. Descriptive Analysis for the Variables of the Study

\begin{tabular}{lcccc}
\hline & NWC & NOI & PM & ROA \\
\hline Median & 3274827 & 573258 & 2.814 & 0.025 \\
Maximum & 490059000 & 303513000 & 362.1614 & 0.6 \\
Minimum & -27315273 & -43653000 & -7413.135 & -1.952 \\
Std. Dev. & 8273592 & 3975203 & 489.9 & 0.168 \\
Probability & 0 & 0 & 0 & 0 \\
Observations & 234 & 234 & 234 & 234 \\
\hline
\end{tabular}

NWC: Net working capital, NOI: Net Operating Income, PM: Profit Margin, ROA: Return On Assets

The Median (M) of the independent variable that measured by the net working capital is 3274827 JD with standard deviation (Std. Dev) of 8273592 JD. This is due to the difference in the sample under study in terms of size and age of company.

More to add, the Median of the dependent variables, measured by the net operating Income, profit margin and 
return on assets, are respectively 573258 JD, 2.814 and 0.025, while the (Std. Devs) are respectively 3975203 JD, 489.94 and 0.168 . The Std. Dev of the net operating income refers to the difference in the sample of study in the general and administrative expenses, selling and distribution expenses which the company takes responsibility for. This difference might be due to the difference in the technology used for the productivity process.

However, the profit margin and the return on assets indicate that the net operating incomes of the sample of study are varying because of difference of the efficiency in the operational and investment process which affects the profitability.

\subsection{Results of Testing Hypotheses and Discussion}

The main hypothesis of the study is: There is no statistically significant relationship at $(\alpha \geq 0.05)$ between the net working capital and the profitability of companies.

According to the results illustrated in Table 3 below, the study finds that there is a relationship between the net working capital and the profitability that is measured by the net operating income, the profit margin and the return on assets.

Table 3. Results of Testing the Main Hypothesis Dependent Variable: Profitability

\begin{tabular}{cccc}
\hline $\begin{array}{c}\text { Method: Panel ELS } \\
\text { Variables }\end{array}$ & Least Squares, & Sample: 2009- 2017, & \multicolumn{2}{c}{ Cross-sections 26, } & observations: 234 \\
Coefficient & T-Test & P- Value(Probability) \\
\hline Net Working Capital & .545 & 9.905 & 0000 \\
$\left(\mathrm{R}^{2}\right)=54 \%$ & & & \\
$\mathrm{DW}=(1.86)$ & & & \\
$\mathrm{F}=98.103$ & & & \\
$\mathrm{Sig}=0.000$ & & & \\
\hline
\end{tabular}

The third table shows a positive relationship between the net working capital and profitability since calculated $\mathrm{F}$ value (98.103) is more than the tabulated value of F (2.60) at ( $\alpha \geq 0.05)$. Moreover, the value of Durbian-Watson test (1.86) indicates that there is no autocorrelation between the errors in the regression equation within the acceptable limits for this test. Thus, according to the calculated T-test value (9.905) which is more than T-tabulated value (1.960), the study reveals not to accept the null hypothesis (H0) and accept the alternative hypothesis, which states that there is a positive relationship between the net working capital and profitability whereas that profitability is measured by the net operating income, the profit margin and the return on assets.

Additionally, the Table shows that the value of the coefficient of determination (R2) is (0.54) which means that the net working capital explains 0.54 of change in profitability; this result clarifies the significance of the net working capital for the industrial Jordanian companies' incomes.

The First Sub-hypothesis (H0-1): There is no statistically significant relationship at $(\alpha \geq 0.05)$ between the net working capital and the profitability of companies whereas that profitability is measured by the net operating income.

The forth table below illustrates the results of testing the first sub-hypothesis by calculating Durbin-Watson test value and T-test value.

Table 4. Results of Testing the First Sub-hypothesis Dependent Variable: Net Operating Income

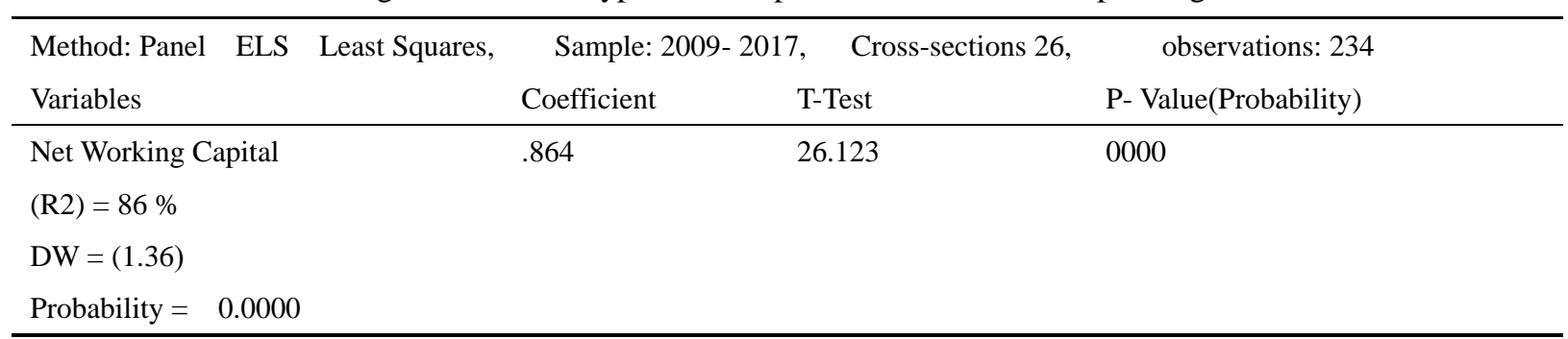

The forth table shows that Durbin-Watson value of the relationship between the net working capital and profitability measured by the net operating income is 1.36 , this means there is no autocorrelations between the errors in the regression equation; they are within the acceptable limits. Therefore, the results of T-test refer not to accept the null sub-hypothesis (H0-1) and accept the alternative sub-hypothesis, which states that "there is a relationship between the net working capital and profitability whereas that profitability is measured by the net operating income".

As the calculated value of T-test (26.123) is more than the tabulated value of T-test (1.960), this means there is a direct relationship between the net working capital and profitability of companies measured by the net operating 
income. However, the value of coefficient of determination $(\mathrm{R} 2)=(0.86)$ means that the net working capital is able to explain 0.86 of change occurred in the net operating income; this result demonstrates the importance of the net working capital for the net operating income of the industrial Jordanian companies.

The Second Sub-hypothesis (H0-2): There is no statistically significant relationship at ( $\alpha \geq 0.05)$ between the net working capital and the profitability of companies whereas that profitability is measured by profit margin.

The fifth table below revealed the relationship between the net working capital and profitability that is presented by profit margin.

Table 5. Results of Testing the Second Sub-hypothesis Dependent Variable: Profit Margin

\begin{tabular}{|c|c|c|c|c|}
\hline $\begin{array}{r}\text { Method: Panel ELS } \\
\text { Variables }\end{array}$ & Least Squares, & $\begin{array}{c}\text { Sample: } 2009- \\
\text { Coefficient }\end{array}$ & $\begin{array}{l}\text { ections 26, } \\
\text { T-Test }\end{array}$ & $\begin{array}{l}\text { observations: } 234 \\
\text { P- Value(Probability) }\end{array}$ \\
\hline $\begin{array}{l}\text { Net Working Capital } \\
\left(\mathrm{R}^{2}\right)=10 \% \\
\text { DW }=(2.004) \\
\text { Probability }=0.75\end{array}$ & & $-.020-$ & $-.311-$ & 0.75 \\
\hline
\end{tabular}

Based on the result of Durbin-Watson test (2.006), the study reveals that there is no autocorrelations between the errors in regression equation which leads to accept the null sub-hypothesis (H0-2) that states there is no relationship between the net working capital and profitability measured by the profit margin since the calculated value of T-test is (- 0.311) is less than the tabulated value of T-test (1.960). On the other hand, the coefficient of determination $(\mathrm{R} 2)=(0.10)$ seems unable to explain the reason of change of profitability due to the profit margin; other factors may explain 0.90 of this change.

The Third Sub-hypothesis (H0-3): There is no statistically significant relationship at ( $\alpha \geq 0.05$ ) between the net working capital and the profitability of companies whereas that profitability is measured by the return on assets.

The results of examining the relationship between the net working capital and profitability measured by the return on assets are illustrated in the sixth table below.

Table 6. Results of Testing the Third Sub-hypothesis Dependent Variable: The Return on Assets

\begin{tabular}{lccc}
\hline $\begin{array}{r}\text { Method: Panel ELS } \\
\text { Variables }\end{array}$ & Least Squares, & $\begin{array}{c}\text { Sample: 2009- 2017, Cross-sections 26, } \\
\text { Coefficient }\end{array}$ & $\begin{array}{c}\text { observations: 234 } \\
\text { P- Value(Probability) }\end{array}$ \\
\hline $\begin{array}{l}\text { Net Working Capital } \\
\left(\mathrm{R}^{2}\right)=20 \%\end{array}$ & .193 & 3.003 & 0.003 \\
$\mathrm{DW}=(1.71)$ & & & \\
Probability $=0.003$ & & & \\
\hline
\end{tabular}

According to Table 6, the results reveal a relationship between the net working capital and profitability measured by the return on assets; this means not accept the null sub-hypothesis (H0-3) and to accept the alternative sub-hypothesis, which refers to the existence of this relationship. The results also demonstrate that the calculated value of T-test (3.0003) is more than the tabulated value of T-test (1.960). However the coefficient of determination is about (0.20); this means $(0.80)$ of occurred change in profitability might be due to other factors not the return on assets. On the other hand, the value of Durbin-Watson test is (1.71) which refers to non-existence of the autocorrelation between the errors in the regression equation which stayed within the acceptable limits of this test.

Through the results reached we see that the investment in net working capital is a positive value for the company, and that there is a strong and positive relationship between net working capital and profitability, through which companies can increase their profits, which is an important part of the company operating, financing and investment policy:

Operationally: if working capital is not available, the company will not be able to increase production to a certain level of sales.

Financially: If there is a shortage of net working capital, it will negatively affect the solvency.

In terms of investment: When working capital is run down, this will increase the cash flow and thus increase the profits.

The findings of the study agree with some the results of the previous studies such as (Popescu and Pirvutoiu, 2009), (Qazi et al, 2011) and (Raheman and Nasr, 2007).

\section{Conclusions and Recommendations}

The study comes out with the following conclusions: 
1. Net working capital is an important part of the company operating, financing and investment policy.

2. The net working capital is considered as a main factor in making financial decisions by redirecting it in the investments that cause positive profitability of companies.

3. There is a positive relationship between the net working capital and profitability; hence profitability is measured by net operating income and return on assets.

4. There is no relationship between the net working capital and profitability; hence profitability is measured by profit margin.

In light of the results of this study, it is recommended to:

1. Pay deep attention on the mechanism of investing the net working capital by selecting prosperous opportunities that make greater incomes for companies.

2. Select efficient people who have good experience in internal and external investments to increase the market share; this may help increase the return on assets and profit margins of sales.

3. Bear into consideration the indicators of profitability by Company Control Department while evaluating the companies.

4. Study, in the future, the field of net working capital and profitability as follows:

A- To conduct this study with different indicators like liquidity and market indicators.

B- Adding other variables to be as control or moderator variables.

\section{References}

AbuHommous, A. (2017). Net Working Capital and Firm Growth. International Review of Management and Marketing, 7(4), 130-137.

Amirthalingam, N., \& Balasundaram, N. (2014). Determinates of Profitability: A Case Study of Listed Manufacturing Companies in Sri Lanka. Merit research journal of Art Social Science and Humanities, 1(1), 1-6. https://www.researchgate.net/publication/236876727

Andrew, F. (2006). Introduction to Project Finance: essential capital market. First published, B.H, Chennai India.

Anjum, N., Saif, M., Malik, Q., \& Hassan, S. (2012). Earnings Management and Firms' Profitability Evidence from Pakistan. European Journal of Economics, 47, 13-18.

Arnold, G. (2008). Corporate financial management, 4 editions, education limited.

Balasundaram, N. (2009). Profitability of Listed Pharmaceutical Companies in Bangladesh, Economical Administrative Series, No 3, 139-148. https://www.researchgate.net/publication/200564635

Brealey, R. A., Myers, S. C., \& Allen, F. (2011). Principle of Corporate Finance, Tenth edition, McGraw-Hill Irwin, New York.

Brealey, R., \& Myers, S. (2006). Corporate Finance, Eighth edition, McGraw hill, New York.

Brealey, R., Myers, S., \& Marcus, A. (2015). Fundamentals of corporate finance, $8^{\text {th }}$ edition, McGraw hill education, New York.

Brigham, E. F., \& Ehrhardt, M. C. (2011).Financial Management: Theory and Practice, South-Western, USA.

Brigham, E. F., \& Houston, J. F. (2007). Fundamentals of Financial Management, eleventh edition, Thomson South-Western.

Dekan, O. (2009). Definition Questions (Profit-Profitability), 4th, Aspects and Visions of Applied Economics and Informatics.

Edmond, T.P., Cindy, D.E., Bor-Yitsay, P.R and Nancy, W.S. (2006). Fundamental Managerial Accounting Concept, McGraw-Hill Irwin.

Ehrahardt, M., and Brigham, E. (2003). Corporate Finance- A Focused Approach, $1^{\text {st }}$ edition, Mason, Thomson.

Evci, S., \& Sak, N. (2018). The effect of working capital management on profitability in emerging countries, evidence from turkey, financial management from an emerging market perspective, published by Intech, open science open minds. https://doi.org/10.5772/intechopen.70871

Fama, E. F., \& French, K. R. (2002). Testing Trade-off and Pecking Order Predictions about Dividends and Debt. The Review of Financial Studies, 15(1), 1-33. https://doi.org/10.1093/rfs/15.1.1 
Gathuya, J. W. (2005). The Relationship between Net Operating Income and The Value of the Firm Quoted at the Nairobi Stock Exchange, Master Thesis published, Faculty of commerce, University of Nairobi.

Gitman, L. J. (2002). Principle of managerial finance, $10^{\text {th }}$ edition, Addison-Wesley.

Gitman, L. J., \&Zutter, C.J. (2012). Principles of Managerial Finance, tenth edition, USA.

Jiricek, P., \& Dostalova, Z. (2010). Financial Management, second edition.

Kaddumi, T. A., \& Ramadan, I. Z. (2012). Profitability and working capital Management the Jordanian Case. International Journal of Economics and Finance, 4(4), 216-226. https://doi.org/10.5539/ijef.v4n4p217

Lamberson, M. (1995). Changes in Working Capital of Small Firm in Relation to Changes in Economic Activity. Mid-American Journal of Business, 10(2), 45-50. https://doi.org/10.1108/19355181199500015

Lee, C. F., \& Lee, A. C. (2006). Encyclopedia of finance, Springer Science and Business media INC, USA.

Meyers, B. (2003). Principles of Corporate Finance, Seventh editions, the MG-Grow- Hill companies.

Nufazil, A., (2018). Do Financial Development and Low Enforceability Effect the Relationship Between Networking Capital and Firm Value? Empirical evidence from Asia. American Journal of Business, emerald Group publishing limited, 33(3), 120-132.

Obara, L. C., \& Eyo, B. O. (2000). Financial Management: Principles and practice, Springfield publishers, Nigeria.

Paramasivan, C., \& Subramanian, T. (2009). New age Financial Management, New Age International, Limited Publishers, New Delhi.

Popescu, A., \& Privutoiu, I. (2009). Analysis of net working capital - A basic tool in business financing. Agricultural Management, 11(3), 1-6,

Qazi, H. A. Shah, S. M., Abbas, Z., \& Nadeem, T . (2011). Impact of working capital on firm profitability. African journal of business management, 5(27), 11005-11010.

Raheman, A., \& Nasr, M. (2007). working capital management and profitability- case of Pakistani firm. international review of business research papers, 3(1), 229-300.

Ross, S. A., Westerfile, R. W., \& Jordan, B. D. (2010). Fundamentals of Corporate Finance, 9 editions, McGraw-Hill Irwin.

Ross, S. A., Westerfile, R. W., \&d Jaff. J. (2003). Corporate Finance, 6 editions, McGraw-Hill Irwin.

Ross, S., Westerfield , R., \& Jaffa, J. (2010). Corporate finance, $9^{\text {th }}$ edition, McGraw hill Irwin, New York.

Shahzad, F., Fareed, Z., \& Zulfiqar, B. (2015). Impact of working capital management of firm's profitability: A case study of cement industry of Pakistan. European researcher, 91(2), 86-93. https://doi.org/10.13187/er.2015.91.86

Sheikh, N. A., Rafique, A., \& Abbasi, M. N. (2016). Impact of Working Capital on Performance of Textile Firm Listed on PSX. Pakistan Journal of Social Sciences, 36(1), 409-419, https://www.bzu.edu.pk/PJSS/Vol36No12016/PJSS-Vol36-No1-36.pdf

Subramanyam, K. R., \& Wild, J. J. (2009). Financial Statement Analysis, Tenth edition, McGraw-Hill.

Vance, D. E. (2003). Financial Analysis and Decision Making, MC Graw- Hill, New York.

Website: www.ase.com.jo.

\section{Copyrights}

Copyright for this article is retained by the author(s), with first publication rights granted to the journal.

This is an open-access article distributed under the terms and conditions of the Creative Commons Attribution license (http://creativecommons.org/licenses/by/4.0/). 